\title{
TINDAK TUTUR DALAM WACANA KELAS VB SD NEGERI 62 KOTA BENGKULU TAHUN PELAJARAN 2012/2013
}

\author{
Parli Saptani \\ saptaparli@gmail.com
}

\begin{abstract}
Penelitian bertujuan untuk mendeskripsikan tindak tutur yang dominan dalam membuka, menerangkan, dan menutup pelajaran dalam wacana kelas menyimak pada kelas $\mathrm{Vb}$ saat membuka pelajaran di SDN 62 Kota Bengkulu tahun pelajaran 2012/2013 didasarkan pada kategori tindak tutur (speech act categories) menurut Sinclair dan Coulthard's (IRF) Penelitian ini merupakan penelitian wacana kelas yang mendeskripsikan wacana kelas. Teknik pengumpulan data pada penelitian ini, yaitu observasi rekaman video. Dari hasil analisis data, diketahui bahwa tindak tutur yang dominan saat pembelajaran, yakni tindak tutur reply sebanyak 82 tindak tutur atau 12, 4\% dari seluruh tindak, directive sebanyak 57 tindak tutur atau 8,6\% dari seluruh tindak tutur, elicitation sebanyak 53 tindak tutur atau 8\% dari seluruh tindak tutur dan nomination 52 atau 7,9\% dari seluruh tindak tutur yang mengarah pada tanya jawab dalam pembelajaran dan penunjukkan pada nama siswa untuk meminta respon. Kesimpulan penelitian menunjukkan bahwa (1) data yang dominan ditemukan tidak cukup menonjol sebagai data yang menjadi penguatan pembelajaran (2) tindak tutur guru sangat dominan dalam pembelajaran sehingga mengabaikan pembelajaran siswa aktif. Implikasi dalam pembelajaran dikhawatirkan akan berdampak pada tercapainya komunikatif pembelajaran yang dalam kurun waktu lama akan berdampak pada mutu pendidikan.
\end{abstract}

Key words: tindak tutur

Pendahuluan

$\begin{array}{llr}\text { Bahasa } & \text { merupakan ekspresi } \\ \text { komunikasi } & \text { manusia } & \text { melalui } \\ \text { pengetahuan, keyakinan, dan perilaku } \\ \text { yang dapat dialami, dijelaskan dan } \\ \text { disebarkan (Trianto, 2008:74). }\end{array}$
Sehubungan dengan itu, bahasa sebagai media komunikasi manusia diperoleh melalui pemerolehan juga pemelajaran. Dalam hal ini kita akan memfokuskan pada pemelajaran bahasa, pada hakikatnya belajar bahasa adalah belajar berkomunikasi, baik lisan maupun tulisan serta ekspresi (Purwanto dan Djeniah Alim, 1997:8). Oleh karena itu, pembelajaran bahasa dan sastra Indonesia diarahkan untuk meningkatkan kemampuan siswa dalam berkomunikasi dengan bahasa Indonesia. Pembelajaran bahasa, selain untuk meningkatkan kemampuan berpikir, bernalar, dan kemampuan memperluas wawasan, juga diharapkan mampu memahami informasi yang disampaikan secara lugas atau langsung dan juga dapat memahami informasi yang disampaikan secara terselubung atau tidak secara langsung. Dengan demikian, pembelajaran harus terjadi secara nyata dan wajar pada lingkungan kelas, sekolah, atau di lingkungan kehidupan anak.

Menyikapi hal ini, salah satu yang

harus dipersiapkan dalam pengembangan peserta didik adalah kemampuan berbahasa Indonesia. Kemampuan berbahasa Indonesia yang dimiliki dapat memenuhi kebutuhannya, seperti kebutuhan perkembangan psikologis, emosi, dan kebutuhan sosial. Selain itu, peserta didik diharapkan dapat mengembangkan diri menjadi warga negara yang baik, menguasai 
IPTEK, dapat bersosialisasi dengan lingkungaanya. Dalam hal ini, guru memiliki peran yang penting sebagai salah satu sumber belajar bahasa.

Guru bahasa Indonsia diharapkan mengajarkan bahasa Indonesia bukan hanya sebagai alat untuk meningkatkan ilmu siswa, melainkan juga untuk meningkatkan daya apresiasi siswa terhadap ilmu. Pada anak-anak usia SD terdapat tiga bentuk proses pemakaian bahasa, yakni mula-mula dengan gerak saja, lalu mengerti akan kata-kata, dan kesatuan-kesatuan bahasa, dan lalu mengucapkan kata-kata dan kesatuankesatuan bahasa. Oleh karena itu, yang perlu kita ingat adalah perkembangan bahasa itu di mulai dari pasif kemudian aktif. Selain itu juga, penggunaan bahasa Indonesia pada guru SD (apalagi pada tingkat rendah) masih banyak dipengaruhi oleh bahasa ibu atau bahasa pertama (B1).

Penelitian tindak tutur bahasa

guru dan siswa saat pembelajaran berlangsung penting dilakukan guna mengetahui bagaimana interaksi guru dan siswa saat pembelajaran. Penelitian ini lebih dikenal dengan analisis wacana kelas yang mengkaji bahasa guru dan siswa sehingga memberikan gambaran dasar seperti apa yang terjadi di dalam kelas. Yang nantinya dapat dijadikan dasar guna peningkatan mutu pembelajaran di dalam kelas yang berimplikasi jauh ke depan akan meningkatkan mutu pendidikan.

Kategori Tindak Tutur Menurut Sinclair dan Coulthard's (IRF) Kategori tindak tutur menurut Sinclair dan Coulthard's (dalam Atkins 2001: 14-15) adalah sebagai berikut:

\section{Marker (penanda)}

Tindak tutur ini disimbolkan dengan huruf ' $m$ ', yakni Penanda untuk membatasi percakapan/jeda percakapan sebelum dan setelah parcakapn dimulai. Contoh : “OK, ... . "Sekarang ... .

\section{Starter (pengantar/ permulaan)}

Tindak tutur ini disimbolkan dengan huruf ' $s$ ', yakni pernyataan/pertanyaan/ perintah yang berfungsi sebagai penyedia informasi, perhatian langsung/pemikiran terhadap sebuah area dalam membuat respon yang benar untuk intonasi yang disukai. Contoh : "Bisakah kamu temukan beberapa pertanyaan?"

\section{Elicitation (pemunculan)}

Tindak tutur ini disimbolkan dengan 'el', yakni sebuah pertanyaan yang berfungsi untuk meminta respon bahasa. Contoh : "Kamu cari beberapa pertanyaan?"

\section{Check (pemeriksaan)}

Tindak tutur ini disimbolkan dengan 'ch', yakni Pertanyaan guru untuk mengetahui pemahaman/situasi siswa dalam mengikuti pelajaran.

Contoh : "Sudah selesai, belum?" "Apakah bisa diikuti?"

\section{Directive (petunjuk, instruksi, perintah)}

Tindak tutur ini disimbolkan dengan huruf ' $d$ ', yakni perintah untuk meminta respon nonverbal.

Contoh : "Lihat pada percakapaannya lagi!" "Coba kamu ulangi lagi, bacanya!"

\section{Informative (informasi/keterangan)}

Tindak tutur ini disimbolkan dengan huruf ' $i$ ', yakni pernyataan yang dibedakan dengan pernyataan lain yang 
fungsi utamanya adalah menyediakan informasi untuk pemahaman/perhatian. Contoh : "Inggris." (jawaban siswa atas pertanyaan guru).

\section{Prompt (anjuran, desakan)}

Tindak tutur ini disimbolkan dengan huruf ' $p$ ', yaknii pernyataan di dalam kelas yang berfungsi untuk memberi penguatan/anjuran/desakan

Contoh : "Lanjutkan ya!"

"Cepat, ya!" "Selesai, belum!"

\section{Clue (petunjuk)}

Tindak tutur ini disimbolkan dengan ' $c l$ ', yakni pernyataan/ pertanyaan/perintah untuk meminta informasi tambahan agar siswa memahami secara langsung.

Contoh : "Bisakah kamu baca paragraf itu?"

"Apakah kita dapat menggunakan garpu tala ini?" "Ya, kita dapat menggunakannya" (cl)

\section{Cue (isyarat)}

Tindak tutur ini disimbolkan dengan huruf pernyataan seiring/ sebelum penawaran/permintaan/ perintah yang berfungsi untuk membangkitkan

Contoh : "Angkat tangan!" "Jangan keluar."

\section{Bid (penawaran/perintah)}

Tindak tutur ini disimbolkan dengan huruf ' $b$ ', yakni penyataan verbal/nonverbal sebagai tanda untuk memberi instruksi pembelajaran bahasa. Contoh : Tujuk tangan, tarik napas, dan menjelentikan tangan

\section{Nomination (pengangkatan penunjukan)}

Tindak tutur ini disimbolkan dengan huruf ' $n$ ', yakni percakapan di dalam kelas agar siswa ikut serta dalam pembelajaran (dengan menyebut nama siswa) yang bukan bertujuan untuk memberi tekanan pada siswa.

Contoh : "Kamu, sekalian." "Ya, kamu, Budi."

\section{Acknowledge (mengakui)}

Tindak tutur ini disimbolkan dengan 'ack', yakni kata- kata/gerakan nonverbal untuk menunjukan pengakuaan/pemahaman atas jawaban siswa

Contoh: "Ya"

"Waw, Ok, Bagus"

\section{Reply (menjawab/menyahut)}

Tindak tutur ini disimbolkan dengan 'rep', yakni pernyataan/ pertanyaan/nonverbal, dengan anggukan untuk mengetahui respon siswa apakah sudah memahami pembelajaran. Contoh: "Mengerti anak-anak?" siswa mengangguk (rep)

\section{React (memberi reaksi)}

Tindak tutur ini disimbolkan dengan 'rea', yakni aksi nonverbal untuk menyatakan respon nonverbal yang tepat secara langsung saat siswa sudah memahami pembelajaran.

Contoh : "gelengan kepala"

\section{Comment (ulasan)}

Tindak tutur ini disimbolkan dengan 'com', yakni Pernyataan/ pertanyaan/penekanan pertanyaan dengan kata "ya" untuk menyamakan informasi tambahan dengan jeda, saat memulai informasi inti (lebih ditekankan pada paralinguistik) 
Contoh : "mmm ... "(sulit dibedakan jika dalam bentuk tulis)

\section{Accept (menyetujui)}

Tindak tutur ini disimbolkan dengan 'acc', yakni pernyataan berupa "ya', "bagus" dalam pengulangan jawaban siswa dengan intonsai yang netral untuk mengidentifikasi bahwa guru telah mendengar/melihat informasi siswa

Contoh : "mmm, Ok"

\section{Evaluate (menilai)}

Tindak tutur ini disimbolkan dengan huruf 'e', yakni pernyataan/penekanan pada kata,frasa berupa komentar dari reaksi/jawaban siswa dengan intonsai tinggi.

Contoh: "Bagus!" "Ya”, "idak"

\section{Silent stress (diam)}

Tindak tutur ini disimbolkan dengan ' $N$ ', yakni pernyataan untuk pembelajaran selanjutnya agar siswa mengetahu pembelajaran yang nanti akan dipelajari

Contoh : "Bekerja dalam kelompok ya!"

\section{Metastatement (konsep tindakan selanjutnya)}

Tindak tutur ini disimbolkan dengan 'ms', yakni pernyataan untuk pembelajan selanjutnya agar siswa mengetahui pembelajaran yang nanti akan dipelajari.

Contoh : "Bekerja dalam kelompok ya!"

\section{Conclusion (kesimpulan)}

Tindak tutur ini disimbolkan dengan 'con', yakni pernyataan dengan nada rendah untuk membantu siswa memahami pelajaran dengan meringkas/menyimpulkan pelajaran. Contoh : "Jadi, ... "Kemudian ..."

\section{Loop (penudingan)}

Tindak tutur ini disimbolkan dengan huruf ' $\mathrm{l}$ ', yakni pernyataan dengan intonasi tinggi yang bertujuan untuk mengulangi pembelajaran sebelumnya yang telah disampaikan siswa secara normal/alami.

Contoh: "Ulangi lagi apa yang kamu katakan!'

\section{Aside (mengalikan pembicaraan)}

Tindak tutur ini disimbolkan dengan huruf ' $z$ ', yakni pernyataan/ pertanyaan/perintah dengan intonasi rendah yang tdak begitu difokuskan pada kelas (kehabisan kata-kata untuk sekadar basa basi).

Contoh :" Dimana saya letakan spidol tadi ya?" "Wah, dingin sekali kelas ini."

Struktur wacana kelas ini berupa model skala peringkat dan berisi lima peringkat, yaitu pelajaran (lesson), yakni pembelajaran secara keseluruhan, transaksi (transaction), yakni adanya hal yang ditransaksikan antara guru dengan siswa, pertukaran (exchange), yakni saling memberi antara guru dan siswa dan adanya pembukaan/pengantar yang diikuti respon dan tindak lanjut yang dilakukan guru dan siswa, gerak (move), yakni adanya pergerakan yang berupa respon atas pertukaran dilakukan guru dan siswa, dan tindak (act), yakni tindakan yang dilakukan guru dan siswa dalam berinteraksi dalam pembelajaran. kelimanya berkaitan satu sama lain. Peringkat ini bersifat hierarkis, unit terbesar adalah 'pelajaran' dan 'tindak' sebagai unit terkecil. Sinclair dan Coulthard's (dalam Trianto, 2012) mengidentifikasi 22 tindak yang menyatu membentuk lima kelompok 'gerak'. Kelompok 'gerak' membentuk 
'pertukaran' sejumlah pertukaran membentuk 'transaksi', beberapa 'transaksi' membentuk 'pelajaran'.

Dilihat dari struktur wacana di atas, pengkajian model analiis wacana ini biasanya terfokus pada tingkat pertukaran.

Pengkajian wacana ini ditekankan pada tingkat pertukaran. Menurut Trianto (2012) ada dua tipe pertukaran, boundary dan teaching. Boundary exchange semacam pembatas awal dan akhir pelajaran, berbentuk framing move atau focusing move. Kedua jenis gerak ini ditandai oleh tindak 'good, well, ok'. Sedangkan teaching exchange, yang terdapat dalam gambar 3, berkaitan dengan proses berkelanjutan kegiatan belajar mengajar yang dilakukan guru, tindak ini dapat ditandai dengan penginformasian (informing), pengarahan (directing), pemunculan (eliciting) atau pemeriksaan (checking). Pengkajian ini berfokus pada pertukaran mengajar yang terdiri atas gerak awal (Initiation move), gerak respon (Response move), dan gerak lanjutan (Follow up move). Stuktur ini dikenal dengan IRF.

Gerak yang menjadi fokus pada initiation adalah elicitation, clue, dan nomination. Gerak yang menjadi fokus pada respon adalah reply. Untuk gerak pada fokus feedback adalah evaluate dan comment.

\section{METODE PENELITIAN}

Data penelitian ini berupa transkrip rekaman bahasa guru dan siswa di SD Negeri 62 Kota Bengkulu. Data rekaman berupa tiga data diberi kode nomor urut pada setiap tindak tutur (act) yang sekaligue menunjukkan jumlah ujaran pada setiap transkrip.
Setiap nomor dalam transkrip merupakan tindak terkecil berupa act dalam AWK. Tindak yang muncul kemudian dikalisfikasikan berdasarkan lima peringkat Sinclair dan Coulthard's untuk mendapatkan kecendrungan dan dominasi.

Analisis data yang dilakukan
adalah mentranskripkan wacana
lisan/video ke dalan tulisan. Data yang berupa tanya jawab antarsiswa dengan siswa, siswa dengan guru di narasikan dalam wacana tulisan. Langkah-langkah menganalisis data (Sugiyono,2011:247252) adalah sebagai berikut :

1. Reduksi Data

Reduksi data merupakan kegiatan mengurangi yang berupa proses penyelesaian, penyederhanaan, pemfokusan, pengabstraksian, dan pentrasformasian. Reduksi data ini dilakukan secara berkesinambungan mulai dari awal pengumpulan data sampai selesai. Kegiatan yang dilakukan dalam reduksi ini ada lima langkah, yaitu (1) memilih-milih data melalui pemusatan perhatian, penyederhanaan, (3) melakukan pengkodean, (4) pengkategorisasian, dan (5) pembuatan memo, intinya adalah menyiapkan dan mengolah data dalam rangka penarikan kesimpulan

Dalam penelitian ini, data yang sudah ditranskripkan kemudian diberi tanda/pengkodean lalu dikalisfikasikan. Adapun pedoman untuk menandai wacana guna dikelompokkan dalam wacana gerak awal (initiations moves), gerak respon/gerak jawaban (responses moves) dan gerak lanjutan (feedback/follow up moves) berdasarkan ciri dari masing-masingnya pada tabel 1. (Kategori tindak tutur menurut Sinclair dan Coulthard's (1990: 14-15)) 
2. Display Data

Display data berguna untuk melihat gambaran keseluruhan hasil penelitian, baik yang berbentuk matrik atau pengkodean, dari hasil reduksi data dan display data itulah selanjutnya peneliti dapat menarik kesimpulan data, memverifikasi sehingga menjadi kebermaknaan data.

3. Kesimpulan dan Verifikasi.

Untuk menetapkan kesimpulan yang lebih beralasan dan tidak lagi berbentuk kesimpulan yang coba-coba, maka verifikasi di lakukan sepanjang penelitian berlangsung sejalan dengan memberchek, trianggulasi dan audit trail sehingga menjamin signifikasi atau kebermaknaan hasil penelitian.

Selanjutnya peneliti memberi kode setiap hasil wawancara dari guru dengan cara memberi nomor urut pada kalimat-kalimat yang dianalisis yakni nomor urut data pada lampiran yang akan memudahkan penganalisisan.

\section{Hasil Dan Pembahasan}

Berdasarkan kategori tindak tutur, ditemukan empat tindak tutur dominan, yakni reply sebanyak 82 tindak tutur atau 12, 4\% dari seluruh tindak, directive sebanyak 57 tindak tutur atau $8,6 \%$ dari seluruh tindak tutur, elicitation sebanyak 53 tindak tutur atau $8 \%$ dari seluruh tindak tutur dan nomination 52 atau $7,9 \%$ dari seluruh tindaktutur.

\section{Tindak Tutur pada Peringkat Lesson}

Model Sinclair \& Coulthard's yang berupa model skala peringkat, yakni dari 22 kategori tindak tutur akan membentuk lima kelompok gerak, yaitu pelajaran (lesson), transaksi (transaction), pertukaran (exchange), gerak (move), dan tindak (act). Untuk gerak pelajaran adalah gabungan dari transaksi yang berupa pelajaran itu sendiri.

Tabel Frekuensi Teaching Exchange

\begin{tabular}{|c|c|c|c|c|c|c|}
\hline NO & \multicolumn{4}{|c|}{ Opening Move } & \multirow{2}{*}{$\begin{array}{c}\text { Framing } \\
\text { Move }\end{array}$} & $\begin{array}{c}\text { Follow Up } \\
\text { Move }\end{array}$ \\
\hline $\begin{array}{c}\text { Tindak } \\
\text { Tutur }\end{array}$ & elicitation & informative & clue & directive & 4 & 10 \\
\hline Jumlah & 49 & 13 & 13 & 40 & 3,1 & 7,8 \\
\hline Persentase & 38,0 & 10,1 & 10,1 & 31,0 & 4 \\
\hline
\end{tabular}

Berdasarkan hasil analsis data, ditemukan transaksi antarguru dengan siswa dalam bentuk gabungan dari exchange bounbdary (pembatas awal dan akhir pembelajaran), yakni framing move ebanyak 4 exchange atau 3,1\% exchange dan focusing move sebanyak 10 exchange atau 7,8\% exchange. Untuk teaching exchange (proses berkelanjutan terhadap pembelajaran yang dilakukan guru) terlihat pada tuturan elicitation sebanyak 49 atau 38\% exchange, tindak tutur informative sebanyak 13 atau $10,1 \%$ exchange, tindak tutur clue sebanyak 13 atau 10,1\% exchange, dan tindak tutur directive sebanyak 40 atau $31 \%$ exchange.

Selanjutnya, kajian tuturan guru dan siswa terhadap wacana membuka, menerangkan dan menutup pelajaran dalam wacana kelas $\mathrm{Vb}$ saat proses belajar mengajar di SDN 62 Kota Bengkulu tahun pelajaran 2012/2013, diketahui bahwa guru dan siswa dalam 
interaksi kelas menggunakan 22 tindak tutur (speech act ategories) menurut Sinclair dan Coulthard's (IRF) (dalam Atkins, 2001).

Terdapatnya 22 tindak tutur menurut Sinclair dan Coulthard dalam wacana kelas ini karena penutur dan mitratutur dalam berkomunikasi menggunakan bahasa dengan membentuk struktur urutan yang ketat dan pola pembicaraan yang sangat terstruktur. Dengan demikian menciptakan deskripsi struktur wacana, berupa tindak bahasa yang ditemukan dalam kelas yang didefinisikan sesuai dengan fungsinya sehingga dapat ditentukan kategorisasinya. Hal ini sesuai dengan pendapat Sinclair dan Coulthard's (dalam Trianto,2012).

Berdasarkan hasil penelitian yang peneliti lakukan dalam wacana kelas membuka, menerangkan dan menutup pelajaran diketahui bahwa tindak tutur yang dominan digunakan guru dan siswa adalah penyahutan (reply), pengarahan (directive), pemunculan (elicitation), dan penunjukan (nomination). Hal tersebut disebabkan dalam memulai interaksi belajar mengajar guru membangun komunikasi dengan memberikan pengondisian terlebih dahulu, seperti perintah untuk segera mengumpulkan tugas dan cendrung untuk menunggu sahutan dari siswa serta dominannya penyebutan nama siswa dalam interaksi di kelas. Hal ini dimaksukan agar siswa harus selalu fokus pada saat pembelajaran berlangsung. (lampiran 8 . HIm: 86)

Berdasarkan teori yang memfokuskan pada IRF (Initiation, Response, dan Feedback), ditemukan data yang dominan muncul dalam pembelajaran adalah tidak cukup memberi penguatan pembelajaran. Adapun data yang menjadi kunci penguatan dalam pembelajaran adalah reply, clue, nomination, elicitation, evaluate, dan comment. Dalam wacana kelas ini memang begitu terstruktur, tetapi sebuah wacana bukan hanya melihat strukturnya saja, melainkan juga melihat maknanya. Sejalan juga dengan kritik Kasper (dalam Trianto,2012), mengatakan bahwa model ini terlalu berorientasi pada guru. Kritik ini menjadi benar adanya pada data yang dominan ditemukan, yakni reply, directive, dan elicitation. Salah satu data saat menerangkan pelajaran, guru melakukan tuturan elicitation, berupa tuturan yang dapat menimbulkan arah materi pelajaran.

Menyikapi hal ini, sejalan dengan pendekatan Cara Belajar Siswa Aktif (CBSA), yakni tingkat sikap guru yang tidak mendominasi dalam proses pembelajaran, kuantitas dan kualitas metode dan media yang dimanfaatkan para guru dalam proses pembelajaran,, dan variasi interaksi guru-siswa dalam proses pembelajaran (Ilham,2011).

Data yang ditemukan menunjukkan pembelajaran yang berlangsung belum menerapkan pendekatan CBSA karena tindak tutur guru masih mendominasi pembelajaran, pembelajaran masih berpusat pada guru. Siswa juga kurang merasa rileks dalam pembelajaran karena tindak tutur nomination juga menjadi dominan dilakukan guru. Dalam interaksi pun guru tidak bervariasi, terlihat dalam tuturan guru yang menggunakan tuturan directive yang cendrung sama dan berulang. Terlihat juga dari data metode yang digunakan guru juga cendrung pada metode tanya jawab karena tindak tutur reply adalah 
paling dominan dalam pembelajaran. Siswa cerndrung menjawab pertanyaan yang dituturkan guru. Menyikapi lebih jauh mengenai hasil temuan ini, untuk jangka panjang dalam pembelajaran dihkawatirkan interaksi dalam komunikasi pembelajaran akan kurang komunukatif dan secara tidak langsung akan berpengaruh pada pembelajaran itu sendiri.

\section{Simpulan dan Saran}

Secara umum simpulan dari hasil dan pembahasan penelitian ini adalah data yang dominan ditemukan tidak cukup menonjol sebagai data yang menjadi penguatan pembelajaran. Tindak tutur yang dominan digunakan guru adalah tindak tutur directive, elicitation, reply dan nomination yang mengarah pada tanya jawab dalam pembelajaran dan penunjukkan pada nama siswa untuk meminta respon.

Dalam pendekatan cara belajar siswa aktif, hasil penelitian ini belum menerapkan pendekatan ini. Hal ini terlihat dominannya tindak tutur yang dilakukan guu serta adanya gerak respon atas tuturan tersebut. Variasi model pembelajaran yang juga diduga kurang bervarisi juga akan berpengaruh pada proses pembelajaran. Ketercapaian pesan dalam tindak tutur menjadikan suasana yang komunikatif juga.

Penulis menyarankan untuk perbaikan penelitian selanjutnya agar menerapkan analisis wacana kelas 22 tindak tutur menurut Sinclair dan Coulthard pada cakupan yang lebih luas, bukan hanya pada satu kelas seperti yang penulis lakukan. Penerapan AWK ini juga dapat dilakukan pada penelitian yang lebih luas lagi pada tingkat sekolah pada seluruh mata pelajaran.

\section{Daftar Pustaka}

Arikunto, Suharsini. 2010. Prosedur Penelitian Suatu Pendekatan Praktik. Jakarta: Rineka Cipta.

Aslinda dan Leni Syafyahya. 2007. Pengantar Sosiolinguistik. Bandung: Refika Aditama.

Atkins, Andrew. 2001. Sinclair and Coulthard,s IRF, Model in A One to One Classroom: Analysis.

Betsy, Rymes. 1990. Classroom Discourse Analysis: A Tool for Critical Reflection. Creekill, NJ: Hampton Press.

Chaer, Abdul dan Leoni Agustina. 2004. Sosiolinguistik Perkenalan Awal. Jakarta: Rineka Cipta.

Chaer, Abdul. 2007. Linguistik Umum. Jakarta: Rineka Cipta.

Danim, Sudarwan. 2010. Pengantar Pendidikan. Bandung: Alfabeta.

Danim, Sudarwan. 2010. Pedagogi Andragogi dan Heutagogi. Bandung Jakarta: Rineka Cipta. 